\title{
Awareness of the Thalassemic Patients' Parents toward Thalassemia in Kirkuk City
}

\author{
Yousif Abdulmuhsin Salih*
}

\begin{abstract}
Background and objectives:- Thalassemia is a blood disorder passed down through families (inherited) in which the body makes an abnormal form of hemoglobin, the protein in red blood cells that carries oxygen. The disorder results in excessive destruction of red blood cells, which leads to anemia. Hemoglobin is made of two proteins: Alpha globin and beta globin. Thalassemia occurs when there is a defect in a gene that helps control production of one of these proteins. There are two main types of thalassemia Alpha thalassemia occurs when a gene or genes related to the alpha globin protein are missing or changed (mutated), it's occur most commonly in persons from southeast Asia, the Middle East, China, and in those of African descent. .Beta thalassemia occurs when similar gene defects affect production of the beta globin protein and it's occur in persons of Mediterranean origin, and to a lesser extent, Chinese, other Asians, and African Americans. There are many forms of thalassemia. Each type has many different subtypes. Both alpha and beta thalassemia include the following two forms the first is Thalassemia major(Cooley's anemia ) while the second is Thalassemia minor patients must inherit the defective gene from both parents to develop thalassemia major while Thalassemia minor occurs if the patients receive the defective gene from only one parent. Persons with this form of the disorder are carriers of the disease and usually do not have symptoms (DeBaun, MR et al. 2011 ). This study aims to assess the thalassemic children's parents awareness toward thalassemia.
\end{abstract}

Materials and method: a Descriptive study have been carried out in Kirkuk Governorate / Al-Azadi teaching hospital, which the nursing and medical care are provide to thalassemic children from September / 2012 to august 2013.

Results: The results of the study showed that Most of the sample is female in age (30 and more) years old. Most of the samples' (56\%) level of education is read and write while only $6 \%$ have bachelor degree .The result indicated that most of the sample $(60 \%)$ have three or more children in their family in addition most of them $(72 \%)$ have only one child incidence by thalassemia, while only $(2 \%)$ of them have three child with incidence of thalassemia. the study indicated that the parents have high rates $(66 \%),(64 \%)(90 \%),(72 \%)$ of acceptable level in knowledge related to definition, singes and symptoms, the transmission method and classification of thalassemia to alpha and beta. The finding also showed that the parents have high rate of unacceptable level in knowledge regarding the genetic factor that causes the disease $(62 \%)$,carriers in thalassemia (78\%), the genetic role in disease transmission (78\%), the causes of each of $\alpha$ and $\beta$ types of thalassemia(60\%), Pathophysiology (94\%), diagnosis methods (74\%) and treatment of minor thalassemia(70\%).

Recommendations: Based on the result of, the investigator recommends Educational program for the parents and families of the children who experienced blood disease including thalassemia. Establishing a special consulting unites for the families of blood disease children's to answer their questions. Encourage the parents of these children to work as a volunteer in the consulting unites to help the new diagnosed cases of thalassemia and their parent to be oriented with their new situations. Provide a Socioeconomic supports to thalassemic patients and to their families.

Keywords: awareness, thalassemia, patients' parents, Kirkuk city

\section{INTRODUCTION}

Thalassemia are hereditary hemolytic anemia characterized by decreased or absent synthesis of one or more globins subunits of the hemoglobin molecule. A Thalassemia results from reduced synthesis of $\alpha$ globulin chains, and $\beta$ Thalassemia results from reduced synthesis of $\beta$ globulin chains (Chene K. and Schwartz E. 1980). It's an inherited autosomal recessive blood disease that originated in the Mediterranean region. In thalassemia the genetic defect, this could be either mutation or deletion, results in reduced rate of synthesis or no synthesis of one of the globin chains that make up hemoglobin. This can cause

* M.Sc in Pediatric Nursing / Instructor in College of Nursing/University of Kirkuk/ E.mail: yousifmuhsin@yahoo.com 
the formation of abnormal hemoglobin molecules, thus causing anemia, the characteristic presenting symptom of the thalassemia (Clegg JB. and Weatheral DJ. , 1999). The two major forms of the disease, alpha- and beta, are prevalent in discrete geographical clusters around the world. Alpha is prevalent in peoples of Western African, found Terai region of Nepal, India and South Asian descent. It is nowadays found in populations living in Africa and in the Americas. It is believed to account for much lower incidence of morbidity and mortality. Beta thalassemia is particularly prevalent among Mediterranean peoples. In Europe, the highest concentrations of the disease are found in Greece, coastal regions in Turkey, in particular, Asian Region such as Izmir and Mediterranean Region such as Antalya, Adana, Mersin, in parts of Italy. The major Mediterranean islands (except the Balearics) such as Sicily, Sardinia, Malta, Corsica, Cyprus, and Crete are heavily affected in particular. Other Mediterranean people, as well as those in the vicinity of the Mediterranean, also have high rates of thalassemia, including people from West Asia and North Africa (Loryl , 1996). Thalassemia usually results in underproduction of normal globin proteins, often through mutations in regulatory genes. Hemoglobinopathy imply structural abnormalities in the globin proteins themselves .The two conditions may overlap, however, since some conditions that cause abnormalities in globin proteins (Hemoglobinopathy) also affect their production (thalassemia). Thus, some thalassemia are Hemoglobinopathy, but most are not. Either or both of these conditions may cause anemia. There are three types of $\beta$-Thalassemia which includes Thalassemia minor or Thalassemia trait which produces mild anemia, Thalassemia intermediate that producing moderate anemia and Thalassemia major, causing anemia requiring transfusion. There are three types of $\alpha$-Thalassemia is includes Alpha trait, a defect in a single alpha chainforming gene, $\alpha$ - Thalassemia minor, a defect with two genes and $\alpha$ - Thalassemia major, a fatal defect in all four alpha chain- forming genes (Chene $\mathrm{K}$. and Schwartz E. , 1980).

\section{MATERIAL AND METHODS}

Non-probability Sampling that consisted of (50) parents having children complaining from thalassemia who visiting AlAzadi hospital in Kirkuk city seeking for medical services for their child. For data collection The instrument was designed and constructed by the investigators to measure the variable underlying the present study, after review of literature. The questionnaire consists of two parts The first part of the questionnaire included demographic data relative to the respondents characteristics such as age ,gender, level of education ,number of the children in the family, number of the thalassemic children in the family. Part two of the questionnaire consists of (12) items includes the structural items concerning knowledge of the sample toward thalassemia This which includes the general information, definition, sign and symptoms and the treatment which is constructed from review of related literatures and previous studies. Interviewing techniques are used. In order to measure the previous items accurately and statistically, the research used the liker scale and scores to find out the knowledge of the parents. In order to find out the levels of awareness or knowledge, cut off points were used to identify the level of knowledge. Therefore the levels of knowledge were determined as a following: 3 2.34 High knowledge (H.K), 2.34 - 1.68 medium knowledge (M.K) and >1.68 Poor OR low knowledge (L.K)( Polit D. and Hungler B., 1999). The data of present study were analyzed through the application of two statistical approaches which may assist for the determination of the study results. These approaches includes Frequencies, Percentage And Mean of scores (L.K)( Polit D. and Hungler B., 1999). The content validity for the early constructed instrument was determined through the use of the panels of experts to investigate the contents of the questionnaire for clarity, adequacy, and relevancy in order to achieve the present study, objectives these experts are: 1 Faculty / University of Kirkuk/ College of Medicine, 1 Faculty / University of Kirkuk / College of Administration and Economic (Biostatics),3 expert from Azady General Hospital/ pediatrics wards and 1 expert from health directorate of Kirkuk / General Health.

\section{RESULTS}

Table (1): Distribution of the demographic data of the sample

\begin{tabular}{|l|c|c|}
\hline Age \\
\hline Items & Frequency & Percentage \\
\hline $21-25$ & 6 & $12 \%$ \\
\hline $26-30$ & 10 & $20 \%$ \\
\hline 30 or more than & 34 & $68 \%$ \\
\hline Total & 50 & $100 \%$ \\
\hline Sex \\
\hline Items & Frequency & Percentage \\
\hline Male & 22 & $44 \%$ \\
\hline Female & 28 & $56 \%$ \\
\hline Total & 50 & $100 \%$ \\
\hline
\end{tabular}




\begin{tabular}{|l|c|c|}
\hline \multicolumn{3}{|l|}{ Level of education } \\
\hline Items & Frequency & Percentage \\
\hline Bachelor & 3 & $6 \%$ \\
\hline Diploma & 7 & $14 \%$ \\
\hline Secondary & 12 & $24 \%$ \\
\hline Read \& write & 28 & $56 \%$ \\
\hline Total & 50 & $100 \%$ \\
\hline Number of the children in the family \\
\hline Items & Frequency & Percentage \\
\hline two child & 9 & $18 \%$ \\
\hline Three child & 11 & $22 \%$ \\
\hline four or more than & 30 & $60 \%$ \\
\hline Total & 50 & $100 \%$ \\
\hline Number of thalassemia child in the family \\
\hline Items & Frequency & Percentage \\
\hline one child & 36 & $72 \%$ \\
\hline two child & 13 & $26 \%$ \\
\hline Three child & 1 & $2 \%$ \\
\hline Total & 50 & $100 \%$ \\
\hline
\end{tabular}

Table (2): Parents knowledge regarding the Definition of Thalassemia

\begin{tabular}{|l|c|c|}
\hline Items & Frequency & Percentage \\
\hline I know & 33 & $66 \%$ \\
\hline Uncertain & 7 & $14 \%$ \\
\hline I don't know & 10 & $20 \%$ \\
\hline Total & 50 & $100 \%$ \\
\hline Mean of score & \multicolumn{2}{|c|}{2.42} \\
\hline $\begin{array}{l}\text { Comparative } \\
\text { Significant }\end{array}$ & \multicolumn{2}{|c|}{ GK } \\
\hline
\end{tabular}

Table (3): Parents knowledge regarding the genetic defect that causes thalassemia happen because of the marriage of two carriers person.

\begin{tabular}{|l|c|c|}
\hline Items & Frequency & Percentage \\
\hline Know & 14 & $28 \%$ \\
\hline uncertain & 5 & $10 \%$ \\
\hline I don't know & 31 & $62 \%$ \\
\hline Total & 50 & $100 \%$ \\
\hline M.S & \multicolumn{2}{|c|}{1.66} \\
\hline $\begin{array}{l}\text { Comparative } \\
\text { Significant }\end{array}$ & \multicolumn{2}{|c|}{ LK } \\
\hline
\end{tabular}

Table (4): Parents knowledge regarding the carriers to thalassemia have no signs or Symptoms, but the diagnosis be through blood tests

\begin{tabular}{|l|c|c|}
\hline Items & Frequency & Percentage \\
\hline know & 5 & $10 \%$ \\
\hline uncertain & 6 & $12 \%$ \\
\hline I don't know & 39 & $78 \%$ \\
\hline Total & 50 & $100 \%$ \\
\hline M.S & \multicolumn{2}{|c|}{1.32} \\
\hline $\begin{array}{l}\text { Comparative } \\
\text { Significant }\end{array}$ & \multicolumn{2}{|c|}{ LK } \\
\hline
\end{tabular}

Table (5): Parents knowledge regarding the role of genetic defect in thalassemia

\begin{tabular}{|l|c|c|}
\hline Items & Frequency & Percentage \\
\hline Know & 9 & $18 \%$ \\
\hline Uncertain & 2 & $4 \%$ \\
\hline I don't know & 39 & $78 \%$ \\
\hline Total & 50 & $100 \%$ \\
\hline M.S & \multicolumn{2}{|c|}{1.4} \\
\hline $\begin{array}{l}\text { Comparative } \\
\text { Significant }\end{array}$ & \multicolumn{2}{|c|}{ LK } \\
\hline
\end{tabular}

Table (6): Parents knowledge regarding the causes of each of alpha- and beta types of thalassemia

\begin{tabular}{|l|c|c|}
\hline Items & Frequency & Percentage \\
\hline I Know & 13 & $26 \%$ \\
\hline Uncertain & 7 & $14 \%$ \\
\hline I don't know & 30 & $60 \%$ \\
\hline Total & 50 & $100 \%$ \\
\hline M.S & \multicolumn{2}{|c|}{1.52} \\
\hline $\begin{array}{l}\text { Comparative } \\
\text { Significant }\end{array}$ & \multicolumn{2}{|c|}{ LK } \\
\hline
\end{tabular}

Table (7): Parents knowledge regarding the Pathophysiology of alpha and beta thalassemia

\begin{tabular}{|l|c|c|}
\hline Items & Frequency & Percentage \\
\hline Know & 1 & $2 \%$ \\
\hline Uncertain & 2 & $4 \%$ \\
\hline I don't know & 47 & $94 \%$ \\
\hline Total & 50 & $100 \%$ \\
\hline M.S & \multicolumn{2}{|c|}{1.08} \\
\hline $\begin{array}{l}\text { Comparative } \\
\text { Significant }\end{array}$ & \multicolumn{2}{|c|}{ LK } \\
\hline
\end{tabular}

Table (8): Parents knowledge regarding the sings of thalassemia

\begin{tabular}{|l|c|c|}
\hline Items & Frequency & Percentage \\
\hline know & 32 & $64 \%$ \\
\hline uncertain & 11 & $22 \%$ \\
\hline I don't know & 7 & $14 \%$ \\
\hline Total & 50 & $100 \%$ \\
\hline M.S & \multicolumn{2}{|c|}{2.5} \\
\hline $\begin{array}{l}\text { Comparative } \\
\text { Significant }\end{array}$ & \multicolumn{2}{|c|}{ GK } \\
\hline
\end{tabular}

Table (9): Parents knowledge regarding the transmission method of Thalassemia

\begin{tabular}{|l|c|c|}
\hline Items & Frequency & Percentage \\
\hline Know & 45 & $90 \%$ \\
\hline uncertain & 2 & $4 \%$ \\
\hline I don't know & 3 & $6 \%$ \\
\hline Total & 50 & $100 \%$ \\
\hline M.S & \multicolumn{2}{|c|}{2.84} \\
\hline $\begin{array}{l}\text { Comparative } \\
\text { Significant }\end{array}$ & \multicolumn{2}{|c|}{ GK } \\
\hline
\end{tabular}


Table (10): Parents knowledge regarding the Diagnosis of Thalassemia by Electrophoresis test

\begin{tabular}{|l|c|c|}
\hline Items & Frequency & Percentage \\
\hline know & 9 & $18 \%$ \\
\hline uncertain & 4 & $8 \%$ \\
\hline I don't know & 37 & $74 \%$ \\
\hline Total & 50 & $100 \%$ \\
\hline M.S & \multicolumn{2}{|c|}{1.44} \\
\hline $\begin{array}{l}\text { Comparative } \\
\text { Significant }\end{array}$ & \multicolumn{2}{|c|}{ LK } \\
\hline
\end{tabular}

Table (11): Parents knowledge regarding the classification of alpha and beta thalassemia are thalassemia major, intermediate and minor

\begin{tabular}{|l|c|c|}
\hline Items & Frequency & Percentage \\
\hline Know & 36 & $72 \%$ \\
\hline Uncertain & 3 & $6 \%$ \\
\hline I don't know & 11 & $22 \%$ \\
\hline Total & 50 & $100 \%$ \\
\hline M.S & \multicolumn{2}{|c|}{2.5} \\
\hline $\begin{array}{l}\text { Comparative } \\
\text { Significant }\end{array}$ & \multicolumn{2}{|c|}{ GK } \\
\hline
\end{tabular}

Table (12): Parents knowledge regarding the Treatment of minor thalassemia

\begin{tabular}{|l|c|c|}
\hline Items & Frequency & Percentage \\
\hline know & 8 & $16 \%$ \\
\hline uncertain & 7 & $14 \%$ \\
\hline I don't know & 35 & $70 \%$ \\
\hline Total & 50 & $100 \%$ \\
\hline M.S & \multicolumn{2}{|c|}{1.46} \\
\hline $\begin{array}{l}\text { Comparative } \\
\text { Significant }\end{array}$ & \multicolumn{2}{|c|}{ LK } \\
\hline
\end{tabular}

\section{DISCUSSION}

\section{Part I:-Discussion of the nurses demographic characteristic distribution}

The sample of the study consist of (50) parents of thalassemic patients who they come with their children to Azadi hospital in Kirkuk city to seek for treatment to their child. Table (1) the results shows that $(68 \%)$ of the sample are in age (30 and more ) years old, more than the half of the study sample $(56 \%)$ are female and this is from the point of view of the researchers that the females are more free to be in company with their children to the hospital in the treatment time and the males (fathers and brother) are connected to work and support the family economically , around (56\%) of the sample are in level of read and write of education while just (6\%) have bachelor degree of education, the result indicated that ( $60 \%)$ of the sample have four children or more in their family while $(72 \%)$ of the sample have one child incidence with thalassemia while only $(2 \%)$ of the sample have three child incidence with thalassemia.

Part II: - knowledge of the parents toward thalassemia

The analysis was conducted on 12 items to assess the thalassemic parents knowledge toward thalassemia regarding to definition, general information, sign and symptoms, types and treatment. Concerning the children's parents knowledge , the study indicated that they have high rates $(66 \%),(64 \%)(90 \%),(72 \%)$ of acceptable level in knowledge related to definition, singes and symptoms, the treatment method and classification of alpha and beta thalassemia.

And from our point of view this it will be because of the parents will experienced the disease , its signs and symptoms and the treatment with the long time of the disease years in their children and follow up to their treatment. Which it is also agreed with what published by (Ayman A.et al., 2008). While the parents have a high rate of unacceptable level in the knowledge regarding the genetic factor that causes the disease $(62 \%)$, signs and symptoms in carriers $(78 \%)$, the genetic role in disease transmission (78\%), the cause of each types of thalassemia (60\%),Pathophysiology (94\%), diagnosis methods (74\%) and treatment of minor thalassemia $(70 \%)$. this will be agreed with the result of our study regarding the level of education of the sample which they contain $56 \%$ of sample are in level of read and write in education level and only there is 6\% have bachelor degree which also are supported by what published in study about the parents attitudes toward genetic diagnosis in Pakistan by Gilani et al., (2007). And also this be supported by study carried out in Greece about thalassemia ,a social problem in Greece by (Matasaniotis and Kattamis, 2000) .which they said there is a wide variable spectrum of problems arising in parents of children with homozygous thalassemia. They depend upon a number of factors, the most important being the educational, economic, social and temperamental status of the family. And this will be supported by what is published in National Center on Birth Defects and Developmental Disabilities about health education and health literacy which he ask to support outreach and education activities for people with thalassemia. and he recommended to develop and translate educational materials for patients and their families and to provide educational materials to community-based providers and service organizations. Focus groups have been used to better understand the issues related to living with thalassemia and have provided useful information for improving 
education and support programs. For that there must be more emphasis regarding information in giving care to patients with thalassemia in the health policy, to perform the parents and the care giver effectively and satisfactory for themselves and for their patients and this will be through educational program, and supporting program to these families. And this supported by (Hamamy H. \& Bittles A.H, 2009) in their publishing in Meeting Individual, Family and Community Needs.

\section{CONCLUSIONS}

Most of the sample is female in age between (30 and more than) years old. Most of the samples' level of education is read and write $(56 \%)$ while only $6 \%$ have bachelor degree . The result indicated that most of the sample $(60 \%)$ have three and more children in their family and most of them $(72 \%)$ have only one child incidence by thalassemia, while only $(2 \%)$ of them have three child with incidence of thalassemia. The study indicated that the parents have high rates $(66 \%),(64 \%)(90 \%),(72 \%)$ of acceptable level in knowledge related to definition, singes and symptoms, the transmission method and classification of alpha and beta thalassemia. The finding showed that the parents have high rate of unacceptable level in the knowledge and bad in formations regarding the genetic factor that causes the disease $(62 \%)$, signs and symptoms in carriers $(78 \%)$, the genetic role in disease transmission $(78 \%)$,the cause of each types of thalassemia(60\%),Pathophysiology (94\%), diagnosis methods $(74 \%)$ and treatment of minor thalassemia $(70 \%)$.

\section{RECOMMENDATION}

Based on the result of the findings of the study, the investigator recommends that educational program for the parents and families of the children who experienced blood disease including thalassemia. Establishing a special consulting unites for the families of blood disease children's to answer their questions. Encourage the families and parents of these children to work as a volunteers in the consulting unites to help the new cases of thalassemia and their parent to be oriented with their new situations. Provide a Social and economic supports to thalassemic patients and to their families. Concentrate on thalassemia and its complications and management in study program in nursing educational program to preparing them to be in good support to the thalassemic patients and their families .

\section{REFERENCES}

Ayman Al Sulaiman, Ahmed Suliman, May Al Mishari, Aziza Al Sawadi and Tarek M. Owaidah. (2008). Knowledge and Attitude Toward the Hemoglobinopathies Premarital Screening Program in Saudi Arabia. Population-Based Survey.32 (6). P.p. 531538.

Chene - Frempong K, Schwartz E. (1980). Clinical features of thalassemia. Pediatric Clinics of North America. 27. P.p. 402-42.

Clegg JB, and Weatherall DJ. (1999). Thalassemia and malaria: New insights into an old problem. Proc Assoc Am Physicians. 111. P.p. 278-282.

DeBaun MR, Frei-Jones M, Vichinsky E. Hemoglobinopathies. In: Kliegman RM, Behrman RE, Jenson HB, Stanton BF. ( 2011). Nelson Textbook of Pediatrics. (19th ed.). Philadelphia, Pa: Saunders Elsevier. chap 456.

Gilani A.I. , Jadoon A.S. , Qaiser R. , Nasim S. , Meraj R. , Nasir N. ,Naqvi F.F., Latif Z., Memon M.A., Menezes E.V., Malik I. ,Memon M.Z., Kazim S.F., and Ahmad U. (2007). Attitudes towards Genetic Diagnosis in Pakistan: A Survey of Medical and Legal Communities and Parents of Thalassemic Children.10. P.p. 140-146.

Hamamy H. and Bittles A.H. (2009). Genetic Clinics in Arab Communities: Meeting Individual, Family and Community Needs Public Health Genomics.12. P.p. 30-40.

Lory FW, Arnopp J, and Cunningham GC. (1996). Distribution of Hemoglobinopathy Variants by Ethnicity in a Multiethnic State. Gene Epidemiol. 13(5). P.p. 501-512.

Matsaniotis N. and Kattamis C. (1996) . Thalassemias, a social problem in Greece. 49(3). P.p.223-30.

Polit , D. and Hungler , B. (1999). Nursing principle and methods. ( $6^{\text {th }}$ ed.). Lippincott, Philadelphia. P.p. 354. 